\title{
INTERNATIONAL PROPOSALS AFFECTING SO-CALLED HUMAN RIGHTS
}

\author{
Frank E. HolmaN*
}

During this last year, as President of the American Bar Association, I have spoken on several occasions regarding the various proposals sponsored by the Economic and Social Council of the United Nations with respect to so-called "human rights." I say "so-called" because the phrase "human rights" is of recent usage and as yet without any adequate or accepted definition. The sponsors of the international human rights program would have this phrase include not only basic rights affecting life, liberty, and property, as heretofore known to lawyers, but also a whole category of social and economic benefits. The Charter of the United Nations refers to "human rights and fundamental freedoms," but without specific definition of what is comprehended or intended by these terms.

Under the terms of the Charter the Economic and Social Council is empowered but not required to "make recommendations for the purpose of promoting respect for, and observance of, human rights and fundamental freedoms for all."

In accordance with this power to recommend, a Commission of Human Rights, acting as a sub-division of the Economic and Social Council, promulgated late in December, I947, a so-called Declaration of Human Rights and a so-called Covenant on Human Rights - two documents. The Commission announced that the Declaration was not to be legally binding on the member states but only to be a declaration of ideals to which the peoples of the world might aspire. The Covenant, however, when ratified by the member nations in the form of a treaty was to have the force and effect of law.

Although, as indicated, it was stated that the Declaration was not to be legally binding, Mrs. Roosevelt and other members of the Commission soon asserted in the United Nations Bulletin, an official publication, that it was, nevertheless, to be treated as an "authoritative interpretation" of the provisions of the Charter.

The personnel of the Commission that produced these two documents is of vital interest to all Americans. Mrs. Roosevelt, as Chairman, was the sole United States representative. It should be pointed out in passing that she is not a person trained in legal draftsmanship, but primarily a social reformer. Australia's representative was Col. William Roy Hodgson-a military man and a person whose experience was largely confined to government service. The United Kingdom's representative was Mr. Charles Dukes-a trade unionist by profession.

These three were the only Anglo-Americans or representatives of English-speaking peoples on the Commission of eighteen members appointed to draft a Bill of Rights

- Mcmber of the bar of Washington; President, American Bar Association, I949-I950. 
for the world including the people of the United States. Canada had no representative, but nevertheless three Russians were put on the commission-Mr. Alfanasi S. Stepanenko, Byelorussian Soviet Socialist Republic, Mr. Michael Klekovkin, Ukrainian Soviet Socialist Republic, and Mr. Alexander E. Bogmolov, Union of Soviet Socialist Republics.

At first there was something of a mystery as to the reason for two documents. It was said that some nations though willing to join in a declaration of principles regarding so-called Human Rights, might not be ready to commit themselves by a treaty obligation to put such rights into force and effect as law. The whole idea of two documents undoubtedly stemmed originally from the hope that the Russians might join in a declaration of ideals but might not join in a formal treaty. It happened, however, as it always does when we undertake to appease the Russians, that Russia would not even join in the Declaration as finally drafted, and that the policy of appeasing Russia, both in the matter of having two documents and in the matter of the loose phrasing of the Declaration and of including therein social and economic benefits and bounties, brought no practical result so far as Russia was concerned.

At all events, to get on with our story in proper sequence, early in 1948 the Commission announced that the Covenant would be held in abeyance until the Declaration was revised and completed and approved by the General Assembly of the United Nations. Thus, the Declaration went through a series of revisions during the course of last year. Since the Commission was meeting in Paris, by the time each revision was available in this country for study and consideration, further revisions and amendments had occurred in Paris. Thus the Declaration was passed last December in Paris when there was no copy of the final draft available in this country to responsible organizations like the American Bar Associationnot even the State Department of our own government had a final copy in this country before approval by the General Assembly of a document which, as to our basic American rights, is nebulous and ambiguous and the latter portion of which sets up a collectivist concept of government for all the peoples of the world including ourselves.

Before attempting to discuss this extraordinary document in any detail it is important to recall clearly that the American concept of a Bill of Rights is that it is a "Bill of Prohibitions" against the encroachments of government. One of the basic principles upon which our government was founded is the idea that men are endowed by their Creator with certain natural and inalienable rights. Never before in history had a government been so organized. Theretofore, governments had granted individual freedom to the citizens if forced to do so or if so inclined, but our forefathers said in effect, "We are endowed by our Creator with certain natural rights and freedoms and the only reason for having a government is to protect these rights and freedoms which we already have." On this basis, our forebears listed in the Constitution those specific functions which they authorized the Fed- 
eral Government to handle and they forbade that Government and its officials to do anything not authorized by the Constitution. To attempt to make this doubly sure the people added a Bill of Rights-really, as already indicated, a "Bill of Prohibitions"-specifically prohibiting the Congress making laws impairing these rights. And then in an effort to make absolutely sure that no government official would in the future misinterpret the proposition that the Federal Government was the servant and not the master of the people-the people added two important overall restrictions that:

r. "The enumeration ... of certain rights shall not be construed to deny ... others retained by the people"-and

2. "The powers not delegated to the United States by the Constitution are reserved to the States or to the people."

Thus, the traditional American theory of government was and is that the rights of the people as to their individual freedoms are personal and inalienable and are not subject to change or modification unless the Constitution is changed by the people themselves. Once a contrary theory is adopted-for example, if we Americans concede that the United Nations Assembly or any other legislative fiat (even the ratification of a treaty by the Senate) or even enactments by Congress or a state legislature can be the source of individual rights-then it follows that the same legislative fiat which confers these rights may withdraw them, limit them, or condition them. It is this basic American concept that is being ignored by the United Nations Commission, and by our State Department. Thus, the whole International Bill of Rights program is predicated on the un-American theory that basic rights can be created by legislative action and that, along with basic rights, the social and economic well-being of our citizens may be defined, fixed, and limited by international declaration.

Though the Russians did not see fit to approve the Declaration, and Mrs. Roosevelt and our State Department have made much of this and have even suggested that only the Russians and the American Bar Association are opposed to the International Bill of Rights program, the Russian refusal to approve was occasioned by objection to the inclusion and exclusion of specific matters-not to the concept that rights can and should be conferred by legislative fiat, for this is the very cornerstone of the Russian philosophy of government. Nor did Russia object to the inclusion in a Bill of Rights of social and economic benefits and bounties to be conferred by legislative fiat. Russia objected, among other things, to any provision such as appears in our own Declaration of Independence, that man is endowed by his Creator with certain inalienable rights. Any reference to God was anathema to the Russians. This matter was debated and in the first draft of the Declaration a compromise was sought on the basis that man was endowed "by nature" with rights. But in attempting to appease the Russians, the Commission finally took this phrase out, with the result that the State Department and our government has now turned 
its back on the traditional concept of individual rights and is in accord with the Russian point of view that a citizen's rights and liberties are to be fixed and defined by legislative fiat.

Our government seems to have lost sight of the basic principles of human liberty and freedom as set forth in our Constitution and Bill of Rights, and by a vast program of propaganda under such persuasive phrases as "achieving human rights for all the world," "achieving social justice for all," and "securing world peace," is attempting to sell a new concept of basic human rights to the American people. This is not new at all but is as old as history itself and is the concept upon which arbitrary governments throughout the whole course of history have functioned, to wit: that basic human rights are dependent upon government fiat.

Even if there were no objection to the content and draftsmanship of the Declaration, even if it were as well drafted as our own Bill of Rights, and even if the Covenant to come were equally well drafted, the whole program would still involve a dangerous violation of our basic American concept of individual rights and freedoms.

But the Declaration as passed in Paris is not well drafted. As heretofore indicated, it is nebulous and ambiguous with respect to basic rights, and the latter portion is an attempt to fasten on the peoples of the world, including ourselves, a collectivist theory of government.

For example, as to basic rights Article 3 of the Declaration states that everyone has the right to life, liberty, and security of person, but this Article does not recognize as co-equal with these rights the right to own property and be secure in its enjoyment. It is true, in Article 77 everyone is accorded the right to own property and no one is to be arbitrarily deprived of his property, but there is no adequate provision that private property is not to be taken for public use without just compensation and without due process of law, as in our own Bill of Rights.

Article Ir provides that everyone charged with a penal offense shall have "all the guarantees necessary for his defense," but this language is too general to have any real meaning. There is no provision for a writ of habeas corpus entitling a man to a speedy trial. The Declaration does not assure a trial by jury impartially selected and does not provide that a man may call witnesses in his favor even at the expense of the state or provide the other safeguards guaranteed to Americans, including the important protection that a man is presumed innocent until proved guilty.

Article 13 provides that "everyone has the right to freedom of movement and residence within the borders of each state." No one can possibly know what this loose language may ultimately be construed to mean.

Article I4 provides that "everyone has the right to seek and enjoy in other countries asylum from persecution." This could easily mean that persons from other countries in the world, feeling themselves persecuted, can move into this country and stay here as long as they see fit.

Article 16 provides that "men and women of full age, without any limitation due to race, nationality or religion, shall have the right to marry and to found a family." 
This means that mixed marriages between the races are allowable without regard to state or national law or policy forbidding such marriages.

Articles 18 and $\mathrm{I} 9$ are so loosely phrased as to "freedom of thought and opinion and expression" that Communists and other subversives are free to impart their doctrines and undermine our institutions without the right on the part of our government to prosecute or deport them. When I made this observation about these Articles in a speech some months ago I was told that such an interpretation of their meaning was absurd. But on March fourth of this year a formal complaint was filed with the United Nations at Lake Success by one of the so-called "consultative" organizations of the United Nations, condemning the trial of the eleven Communists in the federal court in New York as a violation of the "Universal Declaration of Human Rights."

This complaint was filed by a deputation from the International Association of Democratic Lawyers of which Professor Rene Cassin of France is President, and Professor Cassin is a prominent member of Mrs. Roosevelt's Commission on Human Rights.

The complaint charges that the trial of the Communist leaders "attempts to punish the mere advocacy of political thought and opinion" and violates the articles in the Declaration covering freedom of thought, freedom of opinion, freedom of expression, and freedom of peaceful association. The Soviet Union can place this complaint on the Assembly's agenda for action. Thus we have a concrete example of the Pandora's box of complaints of which I spoke a few months ago that can and will be filed by groups and individuals in other countries to supervise and control acts and matters which are our own domestic concern, to be determined by our own national law and procedure. So much for the draftsmanship with respect to basic rights.

Articles 22 to 28, inclusive, of the Declaration constitute an agreement to sponsor a collectivist type of government on an international scale by committing the member nations of the world to a collectivist form of government. These latter Articles do not pretend to limit the powers of government but on the contrary tend to impose so-called economic and social duties upon government-the fulfillment of which will require a planned economy and complete control by government of individual action.

For example, Article 22 provides that everyone has the right to social security; Article 23-that everyone has the right to "just and favorable conditions of work and protection against unemployment" and that everyone has the right to "just and favorable remuneration." Article 24 provides that everyone has the "right to rest and leisure" and "periodic holidays with pay." Article 25 provides that everyone has the right to food, clothing, housing, medical care, and necessary social services and the right to security in the event of unemployment, sickness, disability, widowhood, old age, etc. Article 26 provides that everyone has the right to education and that "education shall be directed to the full development of the human personality 
and to the strengthening of respect for human rights and fundamental freedoms." In other words, education shall be an instrumentality for propagandizing the citizens of the world toward the promotion of a collectivist society as set forth in the Declaration.

The extraordinary over-all commitment in the Declaration is that the "Social Security" to which everyone in the world is entitled is, under Article 22, to be achieved "through international effort and international cooperation and in accordance with the organization and resources of each state." Its loose and general language can easily mean that through international cooperation by Uncle Sam and in accordance with our resources we are to provide, or in a large part provide, social security for all the rest of the world.

It is significant to note that in this connection the Declaration contains no provision for its amendment.

Last November, to wit: November 2, 1948, when it became evident that the Declaration was to be rushed through the General Assembly of the United Nations at Paris, without any adequate opportunity for a study of the final draft in this country, I wrote the then Secretary of State, General Marshall, in Paris, requesting sufficient time for the American people and responsible organizations like the American Bar Association to be advised of what was being approved in their behalf before final action was taken. The Secretary advised me that the Declaration was not to be a document of legal significance, that the Human Rights Commission had devoted three sessions to the development of the Declaration and in addition a Special Drafting Committee had devoted two meetings to the subject, that during the course of the work, the State Department had kept representatives of private organizations, including the American Bar Association, fully informed through consultative meetings, and that the Declaration, in the Secretary's opinion, reflected the traditions and sentiments of the American people. To this letter I replied to the Secretary as follows:

As to basic and traditional American rights, the Declaration is full of meaningless and nebulous language. In its latter provisions the Declaration constitutes an attempt to set up a paternalistic, if not a collectivist, concept of Government for the peoples of the world. In this respect I must deny that the Declaration reflects the traditions and sentiments of the American people.

You state, "The Human Rights Commission has devoted three sessions to the development of the Declaration. In addition a special drafting committee has devoted two meetings to the subject." May I remind you that it took our wise forefathers over eleven years to develop our own Bill of Rights.

You say the Department of State kept representatives of private organizations, including the American Bar Association, fully informed and held "consultative meetings" with them. So far as the American Bar Association is concerned may I respectfully state that you have been misinformed. The Declaration was first promulgated at Geneva on or about December 27, 1947, but copies were not available to any organizations in this country, like the American Bar Association, until well into January 1948. At its very next meeting (February 1948) of the House of Delegates of the A.B.A., in a report, copies 
of which were furnished to the State Department, it was pointed out (page II) that the proposed Declaration and Covenant "contains startling innovations as to Human Rights" and through William L. Ransom and Walter Bastian, representing the A.B.A., representations were made to the State Department that the deadline of April 3, r948, fixed by the Commission for the submission of amendments, gave too short a time for adequate consideration of the documents. The Department of State declined to ask the U. N. Commission for further time. Our American representatives in the United Nations and the other sponsors of the program proceeded to make changes in the Declaration (leaving the Covenant and the measure of implementation in abeyance for the time being). However, information as to the changes being made was not such that any responsible organization in this country had anything like a full disclosure. Neither the press nor the American people were fully or promptly informed of what changes were being approved by our delegates in Paris. Even at the time the Declaration as now passed came to a vote in Paris there was not a copy of the final form of it available in this country for study and comment.

To this reply I received no further answer from General Marshall, and the Declaration was hurried through the General Assembly during the dying hours of its December Session last year in Paris.

As to the view that the Declaration is not intended to have legal force and effect it should be pointed out that all such declarations are nevertheless moral commitments by our country and that they do and will have legal implications. This is already evidenced by the complaint filed on March 4, 1949, with the United Nations against Judge Medina and the further trial of the Communists in New York. Earlier the legal implications of the document were evidenced by the decision of the Supreme Court of the United States holding restrictive covenants regarding residential areas unenforceable (in which case a brief was filed citing the Declaration's provision with respect to "freedom of movement and residence." The effect of such a document is further evidenced by the decision of the California Supreme Court a few months ago regarding mixed marriages whereby that court overturned earlier cases and voided a California statute against mixed marriages. ${ }^{2}$

It is even entirely possible in view of the complaint already filed by the International Association of Democratic Lawyers, that this and other radical if not Communist foreign organizations may contend that the recent dismissal of certain alleged Communist professors from the University of Washington and the action of the Washington State Courts in sustaining the dismissals, is as much a violation of the Declaration of Human Rights as the trial of the Communists before Judge Medina in New York. So it is idle to say that such a document, which after all is an international moral commitment by our government, will have no legal force and effect. It will undoubtedly be cited in many of our courts by individuals or pressure groups of one kind or another and in this way have a direct effect on our domestic law. Thus it will produce confusion in our domestic law and constitute

${ }^{x}$ Shelley v. Kraemer, 334 U. S. I (1948).

${ }^{2}$ Perez v. Lippold, 32 Cal. 2d 7II, I98 P. 2d I7 (1948). 
a continuing basis for complaints by foreigners against our citizens, our judges, and our public officials.

So much for the Declaration.

Mrs. Roosevelt's Commission is now at work on a revision of the Covenant. I have at last secured an assurance from the present Secretary of State that this will not be submitted to the United Nations Assembly for approval this year. It is proposed that when this document has been approved by the General Assembly it will be submitted to the United States Senate for ratification. Under Article VI of our Constitution, if the Covenant is ratified, it will become a part of "the supreme Law of the Land"- "anything in the Constitution or Laws of any State to the contrary notwithstanding." Generally, it is proposed that the Covenant will back up the Declaration.

In other words, under the guise of promoting acceptance of the principles of the Declaration on a voluntary basis, the program envisaged by its sponsors is one of successive commitments in several separate steps-the next step being the Covenant, and the next a program for International Courts to enforce its provisions not only as between states but as against the individual citizens of this and every other country both in their private and in their official capacity if they happen to be officers of government-city, county, state, or federal. Recently there was a vague announcement in the press that Mrs. Roosevelt, upon instructions from the State Department, had announced that the American Delegation could not approve a provision in the Covenant for the trial of American citizens in international courts. Thus the American Bar Association's objection on this score has at last been heeded-but whether effectually heeded will not be known until a revised copy of the Covenant can be examined. Meanwhile we must not be lulled into security even on this point because the Genocide Convention, already approved by the General Assembly, contains a provision for international courts in which citizens of this and other countries may be tried in international penal courts for so-called acts of genocide.

As a part of the program for Human Rights, the Genocide Convention was passed by the General Assembly and is now on deposit with the State Department ready to be submitted to the United States Senate for ratification as a treaty when the State Department so determines. I wrote the Secretary of State regarding the proposed time schedule on this submission and have as yet had no answer.

What is "genocide?" The word was recently coined by a Yale professor. Translated into simple Anglo-Saxon, it means "race-killing." Under this generality of a coined phrase not only a new international crime is created as against states, but also a crime as to persons in their individual or official capacity is created. It goes without saying that all decent men and women are opposed to any program, official or otherwise, which contemplates the destruction of a racial group in whole or in part. But out of this generality of the term "genocide" a Pandora's box of individual crimes is to be created. Not only are acts made punishable which are purely 
domestic in character but also public officials as well as private citizens are to be made amenable to international tribunals for a variety of ill-defined and ambiguous so-called acts of "genocide"-to the extent that the causing of "mental harm" to a member of a group or complicity in so doing is an act of "genocide."

In some states, even Northern states, colored recruits to the National Guard are segregated but equally well cared for and housed. This may nevertheless become an act of genocide since it may be claimed to inflict mental harm on the members of a race, and if it does, the state involved and all its public officials may be charged in an international court with having committed an act of genocide. ${ }^{3}$

Suppose there occurs again an unfortunate situation in some part of this country such as actually occurred with the Negroes in the race riots in Detroit and, some years ago, in New Orleans in connection with the Italians, and as might have occurred during the last war in connection with the Japanese on the West Coast, and the city or state authorities attempting honestly to suppress such riots are charged with not having taken adequate measures to protect the racial group involved, in view of the fact that some members of this race were killed. These public officials may be charged with "complicity in genocide" and brought to trial as individuals upon complaint by persons or groups in this country or by persons or groups in other countries like Russia. Among many other things it is also a part of the crime of genocide to impose measures intended to prevent births within a particular racial group and "complicity in genocide" is also punishable. Therefore, an organization advocating birth control may be punishable in an international court for "complicity in genocide."

In all other countries except the United States even after the ratification of a pact or treaty, the state may decide to what extent it will implement the treaty by the passage of national legislation. We are the only country (except possibly France) facing the peculiar legal situation that when a treaty is ratified by our Constitutional process-by our Senate-its provisions become a part of the supreme law of the land. Article VI of the Constitution provides that a treaty when ratified becomes "the supreme Law of the Land"- "any thing in the Constitution or Laws of any State to the contrary notwithstanding." Hence, if a covenant like the Genocide Convention is ratified as a treaty, it will supersede every city ordinance, every county ordinance, every state law, and every state constitution. Because of this peculiar legal situation our government should be the first to insist that adequate time and opportunity be given the American people and responsible organizations like the American Bar Association to study the provisions of the Genocide Convention, the proposed Covenant, and the program of implementation by and through the organization of international criminal courts.

The House of Delegates of the American Bar Association at the mid-year meeting in Chicago took the necessary action by unanimous vote to put the Association's

\footnotetext{
${ }^{3}$ Sec Art. II, subparagraphs (b) and (c), Art. III, subparagraph (3), and Art. IV of the Genocide Convention.
} 
President and its Committee on Peace and Law in a position to make representations on behalf of the Association to the State Department and to other agencies of the government that an adequate opportunity for study and discussion be afforded the American people before any final action was taken with respect to the Covenant, and particularly before the Genocide Convention was submitted to the Senate of the United States for ratification. As already explained, the State Department has recently indicated that all of $x 949$ will be given to a study of the Covenant before its submission to the United Nations Assembly, but we have had no indication as to how soon the Genocide Convention may be submitted to the Senate for ratification.

The message I want to convey to the lawyers and the people of the United States is that this whole course of action of the United Nations in passing so-called declarations, covenants, and conventions affecting human rights brings us face to face in this country with a new concept in the field of our national law-a concept that is revolutionary in character because among other things it contemplates the trial of American citizens in international penal courts.

The Director of the Division of Human Rights of the United Nations, John P. Humphrey, in a recent article ${ }^{4}$ himself admits that what the Commission is now proposing constitutes an intervention in matters heretofore "within the domestic jurisdiction" of the member states. He admits the whole revolutionary nature of the program by boldly stating:

What the United Nations is trying to do is revolutionary in character. Human rights are largely a matter of relationships between the state and individuals, and therefore a matter which has been traditionally regarded as being within the domestic jurisdiction of states. What is now being proposed is, in effect, the creation of some kind of a supernational supervision of this relationship between the state and its citizens. ${ }^{5}$

Such a program will necessarily produce inevitable conflicts with local law and the internal social and economic conditions in the member nations. These conflicts (even though only matters of interpretation) will likely result in continuous international irritations and provocations instead of contributing to a better understanding between nations.

Moreover, the proposals have serious implications with respect to our form of government. In the United States laws affecting the citizens' life, liberty, and property are passed by established agencies of representative government, to wit: by the Senate and House of Representatives or by the state legislature. On the other hand, the proposal involved in an "International Bill of Rights" is that by and through the use of a treaty, or even without that and simply by and through the adoption of a Declaration by the United Nations Assembly with the approval of the State Department, the fundamental rights and liberties of the citizens of this country will be defined and declared, and in effect legislated, for them without their having any

'International Protection of Human Rights, 255 THE ANNALs 15 (1948).

Id. at $2 \mathrm{I}$. 
voice about it, either by their own votes or through the votes of their duly elected representatives. This is a dangerous, far-reaching and revolutionary change in the processes of constitutional government-the importance of which seems to have been overlooked, in spite of the fact that the revolutionary character of the proposal from the point of view of international law has been openly admitted by the proponents of the program including the Director of the Division of Human Rights himself.

The American people are entitled to be adequately advised, and to be advised by their own government, of the true content and implications of these international proposals affecting human rights, and to have time and plenty of time for their consideration. Because they have not been advised they are either confused, bewildered, or inclined merely to feel that international proposals have no very direct bearing on their individual liberties. Meanwhile, these international political, social and economic programs are being sold under effective generalities or slogans like "social justice," "human rights," "prevention of genocide," or "the achievement of world peace."

The lawyers of America face no greater challenge or opportunity of service to the public than that of advising the American people of the legal and constitutional implications and effects of the various international proposals affecting so-called human rights. 